\title{
Religion and Political Socialization in Context: A Regional Comparison of the Political Attitudes of American Jews ${ }^{1}$
}

\author{
Kenneth D. Wald and Ted G. Jelen
}

The partisanship and ideological self-identification of Southern Jews in the United States are compared with those of Jews living outside the South. While there are few differences in the marginal distributions of these variables between the regions when the South is considered as a whole, we find that Jews living in Southern states other than Florida are more likely to consider themselves conservatives, while Jews living in Florida are more likely to identify with the Democratic Party. Further, political orientations are more differentiated among Jews outside the South. The implications of these findings for more general models of religious socialization are discussed.

Religion has become an important variable in the study of Southern politics. While the study of religion and politics was once a somewhat esoteric concern, religion has become a central concern of political scientists and activists alike (see especially Clark and Prysby 2005). Indeed, it is difficult to find a credible analysis of the 2000 Presidential election which does not assign a prominent role to religion in distinguishing between the "red" (pro-Bush) states and the "blue" (pro-Gore) states. With issues such as gay marriage, relations with Islamic states (and the treatment of Islamic residents of the United States), stem-cell research, private school vouchers, and faithbased initiatives on the political agenda, it seems unlikely that interest in religious politics will slacken in the foreseeable future.

When attention is turned to religious politics in the South, it seems clear that the dominant focus is directed to the realignment of white evangelical Protestants. The shift of the South from a reliably Democratic region to one in which Republicans seem advantaged is one of the most important trends of the final third of the twentieth century (see especially Black and Black 2002; Bullock and Rozell 2003; and Lamis 1984). The shift in evangelical loyalties is an essential component of this transformation (Green et al. 2003; for a contrary view, see Hood et al. 2004). However, there has been little work on the political roles of religiously defined minorities, such as Roman Catholics, Jews, or people from outside the Judeo-Christian tradition. Although few observers would assert that the South is a religious monolith, little systematic attention has been paid to the effects of religious pluralism in the South.

KENNETH D. WALD is professor of political science at the University of Florida.

TED G. JELEN is professor of political science at the University of Nevada-Las Vegas.

The American Review of Politics, Vol. 25, Spring, 2004: 99-116

(C)2004 The American Review of Politics 
Southern Jews are doubly marginal—outsiders in a region dominated by Protestant Christianity, outliers in a community historically concentrated in the urban centers of the East and industrial Midwest. At just one percent of the population, Jews have been bit players in the drama of Southern politics. ${ }^{2}$ Although some have been cast in major roles-Judah Benjamin of Confederate fame, Bob Strauss in Texas, Atlanta mayor Sam Massell-Jews as a whole have usually been consigned to the political chorus in Dixie. By the same token, scholars of American Jewry have paid very little attention to the political or other behavior of Southern Jews. Until the post-war migration to Florida, Southern Jews were considered an exotic species by their brethren, little more than a curiosity for having chosen to live in a region thought "generally impervious to Jewish life" (Whitfield 1988, 363). Both forms of marginality explain the underdeveloped state of research on Southern Jewish politics.

The omission of Jews from research about Southern politics is unfortunate. As we all learn in graduate school, deviant case studies sometimes offer useful insights. Southern Jews constitute an interesting research subject precisely because their outsider status offers a chance to test more general theories about minority behavior and internal diasporas. The current paper begins to challenge this neglect by asking whether Southern Jews exhibit distinctive regional political tendencies. Using data from the National Jewish Population Survey of 2000-2001, the specific focus is on whether Southern Jews are different from non-Southern Jews in their political orientations and the determinants of their political preferences.

The paper is organized in four sections. We begin by describing the basic models employed in the study of Jewish politics and then apply the literature to our central research topic - political similarity or difference between Jews in the South and elsewhere. With the research question clarified, the next section introduces the data set, the variables of theoretical interest, and the statistical model that will guide the analysis. In the section after that, we present the results of empirical analysis to determine whether Southern Jews are politically distinctive both in terms of what they believe and in the factors that structure their preferences. The paper concludes with a discussion of the implications of the findings for theories of regional politics.

\section{Background}

In a seminal article about Jewish political behavior in pre-war Europe, Paula Hyman (1992) isolated two differing conceptual models. The cultural approach posited the development of a common Jewish political ethos largely invariant across time and space. Advocates of the cultural model contend that "elements within Jewish traditional culture, in particular, its 
concern for social justice in the here and now as well as its messianism, when secularized, predispose Jews toward liberalism, anarchism, or socialism" (Hyman 1992, 107). From this perspective, common fate, buttressed by history and strong social ties, promoted Jewish political cohesion regardless of locale. In the alternative, situational approach, scholars attributed Jewish political tendencies to the distinctive features of their immediate social and political context. European Jewish politics were shaped, so it was argued, by the constellation of problems and opportunities facing Jews in each locale, particularly whether the status quo was favorable or hostile to their emancipation. As these conditions might differ sharply from one place to the next, so too did the political choices made by Jews.

Hyman's contrasting models offer a useful way to think about the political impact of region among Jews in the contemporary United States. The cultural paradigm leads us to expect that Jews in the southern United States, drawing on the same tradition and heritage as their non-Southern coreligionists, would be politically identical. In modeling Jewish political attitudes with a regional predictor, we should therefore expect to confirm the null hypothesis. From the situational perspective, however, Southern Jews might well have adapted to the political culture of their region, becoming more like their neighbors and less like their coreligionists. As the contemporary South is more politically conservative than other regions, the Jews of Dixie should diverge in important ways from Jews outside the South. In the empirical model described above, the regional variable should take on statistical significance and enable us to reject the null hypothesis.

Most of the historical literature inspired by Hyman's work embraces the situational perspective, emphasizing political differences among prewar European Jewish communities. Faced with dramatic choices among nationalism (Zionism), socialism (Bundism) and quietism (Ultra-Orthodoxy), European Jewish communities in Europe opted for different choices from one nation to the next or even from one region to another (Mendelson 1993; Medding 1977). If Jews exhibited such disparate political tendencies when they were constrained to live in relatively homogeneous social settings, the vastly freer environment of American Jews today should promote even higher levels of political diversity. The situational perspective has also been buttressed by scholarly research on migration and politics. While this research tradition has generated conflicting findings, most studies appear to conclude that individuals who migrate to new environments adapt to some extent to the political culture of the receiving community (Putnam 1966; Brown 1981). Scholars in the Durkheimian tradition attribute the shift to patterns of interaction and social learning while others put more emphasis on the way that self-interest encourages newcomers to accede to community sentiment. Whatever the behavioral mechanisms, this literature thus leads us 
to anticipate that peripheral Jewish communities populated by migrants from the core area of Jewish settlement areas will be politically distinctive. These expectations are also compatible with the traditional sacred canopy model which posits that dominant religious traditions impart social cues to adherents and non-adherents alike, forging a regional consensus (see especially Berger 1969). Together these bodies of literature suggest that, in most settings, Southern Jews will be more Republican and more conservative than their non-Southern coreligionists.

Hyman's cultural approach, an alternative position that anticipates political uniformity among Jews regardless of locale, finds some support from the emerging market model of religious influence (Finke and Stark 1992; Stark and Finke 2000; Iannaccone 1991). In contrast to the canopy model, this perspective argues that religiosity and group identification are enhanced by competition among denominations. Rather than adapt or merge, minority religions seek to emphasize their distinctiveness from the dominant culture. In order to resist assimilationist pressures of the (locally) dominant culture, religious leaders must engage in what might be termed "product differentiation" by scholars who use economic models to explain religious phenomena (Jelen 2002). Leaders of minority religions have incentives to emphasize the distinctiveness of a particular tradition from the surrounding social environment, and to minimize differences within the minority tradition. In the case at hand, Southern Jews could dissent from the regional consensus by conforming to the political norms exhibited by their non-Southern brethren. On the assumption that Southern Jews will assert their independence from regional culture, we expect to find Southern Jews no more Republican nor liberal than their non-Southern coreligionists.

Despite the imbalance in the literature, the Jewish experience presents a very strong challenge to the situational model with its hypothesis that Southern Jews will differ from their non-Southern Jewish counterparts. As revealed in the National Jewish Population Study of 2000-2001, most Southern Jews can be considered Southern only by virtue of their current place of residence. As Table 1 shows, Jewish residents of the South were for the most part born and presumably raised elsewhere. Only about one-fourth of them were natives of the South. By comparison, over three-quarters of non-Jews who lived in the South were raised in the region. ${ }^{3}$ If we assume that a regional imprint is a function of concentrated exposure to cultural norms, then Southern Jews with their relatively low rates of regional socialization should partake of the more liberal political culture that prevailed in their host society. Under those circumstances, we are unlikely to find significant differences between Jews in Dixie and Jews elsewhere. ${ }^{4}$

The sparse research on Southern Jews does not help us much in choosing between the cultural and situational hypotheses because scholars have 
Table 1. Birth Place of Jews by Region of Residence

\begin{tabular}{lcc}
\hline \multirow{2}{*}{ Region of Birth } & \multicolumn{2}{c}{ Current Residence } \\
& Non-South & South \\
\hline Non-South & $94.1 \%$ & $71.4 \%$ \\
South & $5.9 \%$ & $28.6 \%$ \\
$\mathrm{~N}=$ & 2362 & 762 \\
\hline
\end{tabular}

themselves differed on this question. Much of the traditional historiography of Southern Jewry simply assumed that it represented a unique form of Judaism. Yet in a study of the service organizations established by Southern Jewish women in the 19th century, Bauman (2003) strongly argues in favor of the cultural hypothesis. He notes ". . . when experiences in small towns, ports, commercial cities, and industrial metropolises are compared, similarities far outweigh divergences across the country and . . . a broadly defined 'Jewishkeit,' or mixture of Jewish tradition, custom, values, and historical experience, exerted substantial influence over behavior." He has generalized the argument to the entire Southern Jewish experience:

Jews in the South were influenced by the regional subculture in a relatively marginal fashion. Where they were most influenced, the causal factors were ecological and were not unique to the South. To a remarkable degree, in fact, their experiences were far more similar to those of Jews in similar environments elsewhere in America than they were to those of white Protestants in the South (Bauman 1996, 5).

The point is also debated by scholars who study the role of Southern Jews in the civil rights era. The racial politics of the 1950s and 1960s presented Southern Jewish communities with a difficult choice between adherence to the segregationist norm of their white neighbors or conformity with national Jewish organizations strongly committed to integration (Svonkin 1997). ${ }^{5}$ Most of this literature supports the situational approach by suggesting that Southern Jews largely acceded to the racial status quo (Dinnerstein 1973; Forman 1997; Greenberg 1998; Mohl 1999). Unlike their northern counterparts who championed the black cause and cheered on Jewish college students who came south for Freedom Summer, Southern Jews were stymied by recognition that "their acceptance as whites was entirely conditional upon their continued compliance with the prevailing social order" (Webb 2001, xiv). Some scholarship (Bauman and Kalin 1997; Webb 2001) offers a more nuanced view. It suggests that younger Jews, Jews with shallower roots in the South, Jews in urban and metropolitan areas, and Jewish religious 
leaders managed to resist regional culture. Working on behalf of the civil rights movement, they represented a kind of Northern Jewish outpost in the inhospitable climes of Dixie. The literature on this critical period can thus lend support to either the cultural or situational approach. In the absence of more focused research from the recent past, we have no reason to prefer one over the other. ${ }^{6}$

The foregoing discussion speaks to one of our research questions-are Southern and non-Southern Jews alike in what they believe politically? We are equally intrigued by whether they differ in how their beliefs are formed. That is, do the same variables differentiate and structure political views for Jews in the South and elsewhere? While the cultural model would answer the question negatively, seeing Southern Jews as replicates of their nonSouthern coreligionists, the situational model allows for the possibility that the dynamics of political attitudes might differ between the two groups. The market model speaks to this issue. In settings in which a religious tradition (such as Judaism) is a small minority, religious and cultural leaders lack both resources and incentives to promote divisions within the tradition. Rather, one would expect efforts to focus on the similarities that exist among members of the tradition.

An example may clarify this last point. Although there are very few jurisdictions in the United States in which Jews would constitute anything close to a majority of the population, in some settings (e.g. large cities in the Northeast and Midwest), there exist a sufficient number of Jews (in an absolute sense) to sustain multiple synagogues. A Jew living in New York, or in the North suburbs of Chicago, may choose among Orthodox, Reform, or Conservative congregations, and perhaps even among synagogues within each of these branches of the tradition. Indeed, the market model predicts that, given a critical mass of potential members, leaders of different denominations will need to compete among themselves, and to offer diverse theological, social, and (perhaps) political emphases. Conversely, in a community where the number of Jews is too small to sustain more than one temple, such differences among branches of Judaism are likely to seem more threatening to a shared Jewish heritage. The synagogue example, of course, can be extended to include businesses (grocery stores, restaurants), community organizations, or local media. The general point here is that intra-Jewish differentiation may not be a viable option in communities in which multiple Jewish institutions are not feasible.

While we cannot assume that a regional analysis within one society will necessarily match a cross-national comparison, there is a small body of comparative research with potential relevance to this expectation. Wald and Martinez' analysis of the Israeli and American Jewish communities (2001) 
largely supported the idea of identical cleavages among widely-separated Jewish communities. While some variables structured the vote in one society and not the other or pulled the two communities in altogether different directions, the same relationships were usually observed between major social background traits and attitudes. That is, qualities like religiosity, gender, age and the like exerted the same directional influence on political orientations among Jews in the United States and Israel. Extending the analysis to Jews in the United States, Great Britain, and South Africa, Kotler-Berkowitz (2002) found the same general pattern. Religiosity had a powerful and identical influence on political differences among Jews in all three societies while other predictors had variable effects from one community to the next. Unlike the first research question, where we have fairly strong reasons to anticipate confirming the null hypothesis, this second question about attitudinal structuring may well generate strong situational patterns.

\section{Analytic Strategy}

The data for analysis were obtained from the National Jewish Population Survey of 2000-2001 (NJPS), a periodic study supervised by the United Jewish Communities and the Jewish federation system in the United States. The data were obtained by random digit dialing of a stratified probabilitybased sample of U.S. residential telephone numbers. A maximum of eight efforts were made to contact targeted households between August, 2000 and August, 2001. The survey, with fieldwork conducted by RoperASW (formerly Audits and Surveys Worldwide), yielded a response rate of $28 \%{ }^{7} \mathrm{~A}$ total of about 4500 Jewish adults were interviewed although we restrict our attention to the smaller set of respondents who were classified as Jews rather than "persons of Jewish background."

We focus on what political scientists consider core or basic political values (and the only suitable dependent variables in the survey) - partisan identification and self-described ideology. Partisanship was measured by an ANES-style question, "Generally speaking, do you think of yourself as a Republican, Democrat, Independent, or Something else?" Because the survey did not use a branching style question that more finely allocates respondents to partisan categories, the proportion of Independents is likely to be somewhat inflated. We created an ordinal scale where Republicanism was the lowest value, Democratic the highest value, and Independent and other constituted the midpoint. The ideology measure asked respondents to characterize their political views on an seven-point scale ranging from "extremely liberal" to "extremely conservative" with moderate as the midpoint. 
The principal independent variable, region, is measured by region of residence. All respondents who were contacted in the Census Bureau's southern region were classified as Southerners and assigned a value of 1 on the dummy variable. ${ }^{8}$ We also created a dummy variable that identified respondents living in Florida (about $43 \%$ of Southern respondents). In the state of Florida, Jews represent a sizable, politically consequential minority, and thus seem likely to inhabit environments different from Jews living in other Southern states.

The other predictors of Jewish partisanship and ideology were drawn from previous empirical research: gender, ethnicity, education, age, religious observance, and communal integration. ${ }^{9}$ Among American Jews, education, age and communal integration have generally encouraged both Democratic affiliation and self-identification with liberalism (Lazerwitz, Winter, and Dashefsky 1988; Legge 1995). (In studies of the general population, age and education are usually inversely related to these dependent variables, highlighting the political exceptionalism of American Jewry.) There is strong evidence from both the Wald-Martinez (2001) and Kotler-Berkowitz (2002) studies that religious observance diminishes Democratic identification and liberalism. Based on evidence from the general population, there is reason to anticipate that males will be less Democratically-inclined or liberal than females.

The research strategy proceeds in two steps. The first set of analyses attempts to determine whether Southern Jews are indeed different in partisan affiliation and ideological self-identification from Jews who live elsewhere. This will be assessed both by a simple comparison of central tendency between the two groups and by multivariate models of partisanship and ideology that include the regional dummy variable. A significant, non-zero coefficient for the dummy will indicate regional distinctiveness and thus support the situational model. In the second step, we examine whether the predictors of Jewish political orientation operate the same way among Southern and non-Southern Jews. Using the slope dummy approach (Hanushek and Jackson 1977), the analysis will include the regional dummy and multiplicative terms representing the interaction of region and each predictor. We will compare the coefficients for the non-South and South conditions. The statistical model will tell us if the impact of the various predictors differs from zero among Southerners and non-Southerners. Auxiliary analysis, a pooled variance t-test on the difference in the coefficients, enables us to determine whether the slopes are significantly different from each other and will identify whether the factors do indeed operate distinctively across regions. Because the dependent variables are ordinal, the multivariate model is estimated with ordered logit. 
Table 2. Regional Differences in Party Identification

\begin{tabular}{lcc}
\hline & \multicolumn{2}{c}{ Region of Residence } \\
Party Identification & Non-South & South \\
\hline Republican & $14.3 \%$ & $16.8 \%$ \\
Independent & $29.1 \%$ & $25.1 \%$ \\
Democratic & $56.6 \%$ & $58.0 \%$ \\
$\mathrm{~N}=$ & 2772 & 851 \\
\hline
\end{tabular}

\section{Patterns of Partisanship}

The bivariate relationship between region of residence and party identification is rather unimpressive. As Table 2 reveals, Southern Jews differ from non-Southern Jews not in the direction of their partisanship but in their level of polarization. Jews in Dixie are less likely to be Independents than their compatriots. Even that difference falls far short of statistical significance using the familiar Kendall's tau-b measure. Ignoring any compositional differences between the two groups of Jews, we simply note that this first test lends strength to the cultural rather than the situational model.

More demanding multivariate tests of regional differences in partisanship reinforce the conclusion drawn from bivariate analysis. Taking into account the factors that differentiate Jewish political behavior, Southern residence (Model 1) is not a significant influence on partisanship, when Southern residence is undifferentiated by state. When we take account of the factors usually found to influence Jewish political attitudes, the regional factor is not a strong predictor. The other predictors operate precisely as expected in both models. Democratic identification is enhanced by education, age, and white, non-Hispanic status. Communal involvement with Jewry, a psychological measure of perceived common fate, also promotes Democratic affiliation. On the other hand, being male and more religiously observant translates into a Republican propensity. All these measures exceed the threshold of statistical significance. However, when residents of Florida are distinguished from Jews living in other Southern states, we do find that Jews who reside in Florida are significantly more likely to identify with the Democratic Party.

The next issue is whether Southern Jewish partisanship is structured in the same way as party identification among non-Southern Jews. To explore that possibility, we extend the models in Table 3 to include interaction terms. The coefficients, known as slope dummies, tell us how the predictors operate among Southern and non-Southern Jews. A pooled variance t-test 
Table 3. Models of Jewish Partisanship

\begin{tabular}{|c|c|c|c|c|}
\hline & Model 1 & Model 2 & Model 3 & Model 4 \\
\hline Non-Southern Residence & .003 & .184 & -.220 & -.198 \\
\hline Male & $-.668 * * *$ & $-.670 * * *$ & & \\
\hline White, Non-Hispanic & $.451 * * *$ & .430 & & \\
\hline Education & $.090 * * *$ & $.095 * *$ & & \\
\hline Age & $.007 * * *$ & $.006 * *$ & & \\
\hline Religious Observance & & & $-.030 *$ & $-.038 * *$ \\
\hline Communal Identification & $.037 * * *$ & $.040^{*}$ & & \\
\hline Florida Residence & & $.357 *$ & & $.360 *$ \\
\hline Non-Southern * Male & & & $-.709 * * *$ & $-.710 * * *$ \\
\hline Southern * Male & & & $-.533 * * *$ & $-.542 * * *$ \\
\hline Non-Southern * White, Non-Hispanic & & & $.572 * * *$ & $.567 * *$ \\
\hline Southern * White, Non-Hispanic & & & .125 & .059 \\
\hline Non-Southern * Education & & & $.096 * *$ & $.095^{* *}$ \\
\hline Southern $*$ Education & & & .065 & .084 \\
\hline Non-Southern * Age & & & $.006 * *$ & $.006 *$ \\
\hline Southern * Age & & & $.009 *$ & .007 \\
\hline Non-Southern * Religious Observance & & & $-.032 *$ & $-.039 *$ \\
\hline Southern * Religious Observance & & & -.025 & -.035 \\
\hline Non-Southern * Communal Identification & & & $.036^{* * *}$ & $.039 * *$ \\
\hline Southern $*$ Communal Identification & & & $.041 *$ & $.046 * *$ \\
\hline$* \mathrm{p} \leq .05, * * \mathrm{p} \leq .01, * * * \mathrm{p} \leq .001$ & & & & \\
\hline
\end{tabular}

will indicate whether the difference between slopes for the two groups is statistically significant. ${ }^{10}$

According to Table 3, regional residence did not contribute significantly to Democratic identification nor did the cleavage patterns indicate unique partisan dynamics for the Jews of Dixie when Florida residents are combined with other Southern Jews. With region defined by residence (model 3), male Jews were less likely to identify with the Democratic Party than females in both the Southern and non-Southern subsamples. Similarly, age and communal integration operated to promote Democratic affiliation in both regions. Certain factors that structured partisanship among Jews outside the South did not affect the Jews of Dixie at all. Thus education enhanced Democratic partisanship among non-Southern Jews but not among Jews in the South. The same pattern held for racial-ethnic identity and, most significantly, for religious observance. Non-Southern Jews grew more Republican as they increased their level of ritual observance but Southern Jews showed 
no such tendency. However, a test of the significance of the pooled variance indicated that these differences in slopes could be attributed to sampling error. There is no basis in Table 3 to conclude that partisan dynamics differ between Jews based on whether they reside in the South or not.

Similarly, when residents of Florida are considered separately in the fully specified model (Model 4), Floridians remain more likely to selfidentify as Democrats. However, the regional dynamics of partisan identification remain the same even when the Florida dummy is added to the model.

\section{Patterns of Ideological Identification}

Turning attention to our second dependent variable, ideological selfidentification, we find interesting continuities and contrasts with our analysis of party identification. With seven ordered response categories, we can treat the ideology variable as if it were interval. The difference in means between Southerners (4.54) and non-Southerners (4.65) does run in the predicted direction, with the former scoring lower. However, the mean difference of 0.11 does not meet the standard .05 level of statistical significance. Thus, again, the simple regional comparison reveals no differences between Southern Jews and those living outside the South.

Table 4 contains the same multivariate analysis with ideology as was performed above with partisanship. While the models are not identical to the findings for partisanship, they do agree about the failure of non-differentiated Southern residence to distinguish the political orientations of Jews in the South from Jews elsewhere. In Models 5 and 7, the regional dummy is statistically indistinguishable from zero when the appropriate factors are controlled. As for partisanship in Table 3, liberalism is positively predicted by education but diminished by gender and religious observance. Neither communal identification, ethnic status, nor age affects ideology in either model.

Model 7 provides a fully-specified model of ideological identification, without differentiating between Floridians and other Southerners. Once again, the Southern residence variable does not exert a significant impact on liberalism and most of the factors work the same way among Southern and non-Southern residents. Maleness (negative) and education (positive) have the same significant influence on ideology in both subsamples while racialethnic status and communal identification do not matter for ideology in either group. The negative effect of age and religious observance on liberalism is confined to non-Southern Jews and the slopes for those two variables are also significantly different across region. Thus we find another two cases where variables that structure political attitudes among non-Southern Jews do not differentiate among Jews who reside in the South. 
Table 4. Models of Jewish Ideology

\begin{tabular}{|c|c|c|c|c|}
\hline & Model 5 & Model 6 & Model 7 & Model 8 \\
\hline Non-Southern Residence & .115 & $.225^{*}$ & .787 & $.883 *$ \\
\hline Male & $-.517 * * *$ & $-.518 * * *$ & & \\
\hline White, Non-Hispanic & .113 & .093 & & \\
\hline Education & $.263 * * *$ & $.265 * * *$ & & \\
\hline Age & -.002 & -.003 & & \\
\hline Religious Observance & $-.084 * * *$ & $-.093 * * *$ & & \\
\hline Communal Identification & .002 & .005 & & \\
\hline Florida Residence & & $.249 *$ & & .162 \\
\hline Non-Southern * Male & & & $-.536 * * *$ & $-.535 * * *$ \\
\hline Southern $*$ Male & & & $-.461 * * *$ & $-.465 * *$ \\
\hline Non-Southern * White, non-Hispanic & & & .042 & .034 \\
\hline Southern * White, Non-Hispanic & & & .415 & .385 \\
\hline Non-Southern * Education & & & $.287 * * *$ & $.286^{* * *}$ \\
\hline Southern $*$ Education & & & $.202 * * *$ & $.210 * * *$ \\
\hline Non-Southern * Age & & & $-.005 * * *$ & $-.006^{*}$ \\
\hline Southern * Age & & & .004 & .004 \\
\hline Non-Southern * Religious Observance & & & $-.109 * * *$ & $-.119 * * *$ \\
\hline Southern * Religious Observance & & & -.007 & -.012 \\
\hline Non-Southern * Communal Identificatio & & & .002 & .005 \\
\hline Southern $*$ Communal Identification & & & -.000 & .001 \\
\hline$* \mathrm{p} \leq .05, * * \mathrm{p} \leq .01, * * * \mathrm{p} \leq .001$ & & & & \\
\hline
\end{tabular}

As was the case with our analysis of partisanship, separate consideration of Florida residents does make a difference. In the simple regional comparison (Model 6), residence in Florida is related to higher levels of liberal self-identification, while Southern Jews who live outside of Florida are more likely to call themselves conservatives. In the fully specified model (Model 8), the effects of living in Southern states other than Florida retain their effect on conservative ideological identification, but the tendency of Jews residing in Florida to consider themselves liberals is no longer statistically significant.

\section{Interpretation}

Regarding our first line of inquiry, whether Southern Jews hold different political positions than their non-Southern coreligionists, the evidence is decidedly mixed. In both bivariate and multivariate analyses, Jews living in 
the South are no less and no more inclined to identify as Democrats or liberals than Jews who reside elsewhere, when the South is considered as an undifferentiated cultural unit. However, when an empirical distinction is made between Jews residing in Florida, and those residing in the rest of the South, intriguing differences emerge. Jews living in southern states other than Florida tend to be more ideologically conservative than their northern counterparts, and this difference is apparent even with the imposition of elaborate multivariate controls. Conversely, Jews residing in the state of Florida are significantly more likely to identify with the Democratic Party.

We are not in a position to offer a definitive explanation for these findings, but, taken together, they provide support for both the situational and cultural models. We hypothesize that Southern Jews living outside of Florida are exposed to predominantly conservative political cues, and have adapted to some extent to the dominant political culture. Jews residing in most Southern states appear to have a tendency to adapt to the local ideological climate, which supports the prediction generated by the situational model. In Florida, the cultural model appears to have some empirical support. The most likely explanation for the greater tendency of Jews to identify as Democrats is simple partisan inertia. Since our data show that a large majority of Southern Jews are migrants from other parts of the country, we hypothesize that Jews living in Florida have simply retained the party identification they held before moving to Florida. The ideological and partisan diversity of Florida suggests that there is no dominant cultural norm to which recent migrants can adapt.

When we look to the second research question, whether the attitudes of Southern Jews are structured differently than their non-Southern brethren, the evidence is mixed. Certainly, many of the coefficients suggest that the two groups of Jews respond similarly to various social forces. Sometimes, a factor has a significant influence on Jews in the two categories and other times it makes no difference in either the South or the rest of the country. But we also found several cases where the dynamics of opinion holding differed across regions. In two such cases, age was a significant influence on non-Southern Jews, enhancing Democratic identification and diminishing liberalism, while Southern Jews were not politically responsive to that factor. Religious observance, which Kotler-Berkowitz described as the most consistent source of political differences among Jews cross-nationally, differentiated Jews on ideology outside the South but not Jews resident in the South.

Of the cases when a variable was influential in one region but not in another and the difference in slopes reached statistical significance, the direction was identical. In each case, the variable operated powerfully among non-Southern Jews but failed to divide Jews in the South. The 
direction of the relationship is consistent with the market model of religious affiliation. In that emerging tradition, internal differentiation within a religious tradition ultimately depends on the ability to sustain multiple social and religious institutions. Whether the focus is on formal institutions such as synagogues, or on more casual associations such as friendships, a strong sense of separation from outside the religious tradition may produce greater pressure for conformity within Judaism. It is difficult for anyone to maintain unpopular views (political or religious) without some sort of social reinforcement and affirmation. In the South, the availability of such social resources for Jews is likely to be relatively limited, and, therefore, Jews born in the South (who do not experience the effects of socialization in more pluralistic environments) might well come to regard intra-tradition conformity as an essential component of their Jewish identities. ${ }^{11}$

The political behavior of Southern Jews thus exemplifies both cultural and situational responses. Clearly, Jews who live in the South identify with the same political norms as the rest of American Jewry. Perhaps because Southern Jewry is a relatively modern phenomenon, at least in mass terms, there simply has not been time for the impact of Southern residence to erode the political values that Jews inherit. However, Southern residence sometimes leaves an imprint in the form of greater cohesion. Somewhat ironically, what makes Southern Jews politically distinctive is their difference from other Southerners, not from other Jews. In some cases, they tend to hold different views than their non-Jewish neighbors. Even the distinctive dynamics of their beliefs tend to set them apart from other Southerners. In all cases where Southern residence affected a political orientation differently than it did for other Jews, the distinctive Southern pattern was greater cohesion. As the market model suggests, their minority status encouraged the development of a strong identity that manifested itself as a unique political style in Dixie.

Much of the research on Southern Jewry documents an almost desperate urge by the Jews of Dixie to blend in, to become part of the dominant majority. While our data provide some qualified support for that position, other possibilities abound. Historians have noted the erosion of a Southern Jewish presence outside the great urban centers of Jewish settlement-South Florida, Atlanta, Charlotte, Dallas, etc. What became of the Jews in the countless small towns scattered across the region where a small Jewish presence was once documented by memoir? The Museum of the Southern Jewish Experience in Jackson, Mississippi displays artifacts from these communities in the manner of archaeological exhibitions of long dead civilizations. Perhaps we have missed the full impact of the situational model by ignoring the Jews who might have assimilated to the point of no longer claiming or reporting a Jewish background. The Jewish ghosts of Missis- 
sippi may reveal the best evidence of the power of assimilation but they, of course, are not included in the data set.

\section{NOTES}

${ }^{1}$ We are grateful to Laurence Kotler-Jacobs of the United Jewish Communities for his comments on an earlier draft of this manuscript. The United Jewish Communities should be congratulated on making the data so freely available to users.

${ }^{2}$ This figure, calculated from the American Jewish Year Book 2003 (Singer and Grossman 2003), follows the Census Bureau's somewhat generous definition of the South. Apart from the eleven former states of the Confederacy, this includes Washington DC, Delaware, and West Virginia.

${ }^{3}$ This estimate is based on the American National Election Studies, 2000. That survey does not ask state of birth but rather state where the respondent was raised. On the assumption that some of the Southern Jews outside the region were raised in the South, this comparison overstates the contrast in nativity between Jews and non-Jews.

${ }^{4} \mathrm{On}$ the other hand, as the literature review discloses (see below in text), this hypothesis might be sustained in historical research. As Whitfield (1988) argues, the Southern Jewish communities of the pre-World War II era, too small in number to resist the larger culture, assimilated to the host culture and became, in a sense, more Southern than the Southerners.

${ }^{5}$ We should not assume cohesive support for civil rights among Northern Jews either. When the claims of the movement went beyond de jure to de facto segregation and challenged white dominance of institutions where Jews enjoyed substantial representation, many Jews resisted (Rieder 1985).

${ }^{6}$ Reed's early study (1979), constructed by isolating Southern Jews from aggregated Gallup surveys, yielded too few respondents for reliable projection or for subgroup analysis.

${ }^{7}$ The report is available at www.ujc.org/njps and the data and documentation are available for download at www.jewishdatabank.org.

${ }^{8} \mathrm{We}$ also conducted analyses in which we considered the effects of being a "native" Southerner (having been born in the South). We find no systematic differences between the results of those analyses and the findings reported here.

${ }^{9}$ The measurement of most of these variables was straightforward. Religious observance was based on a scale with five items about ritual behavior connected to Sabbath, Hannukah, Passover, Yom Kippur and the dietary laws. (The scale had an alpha value of .75.) While it might have been simpler to use synagogue attendance, that item was asked of only a fraction of the sample and would have reduced the number of usable cases. Moreover, the ritual belief scale might well be a better indicator of how Judaism defines piety. Communal integration, a measure of cognitive identification with Judaism, was based on a thirteen item scale with an alpha value of .81. This scale incorporates various forms of association with Judaism and other Jews, such as the importance of Judaism to self-image, life decisions, and friendships and public acts of identification including a mezzuzah on the residence and contributions to various Jewish communal organizations. It also has an item about level of emotional identification with the state of Israel and the tendency to seek out Jewish places of interests when traveling. While previous research has indicated some correlation between strictly religious observation and communal 


\section{4 | Kenneth D. Wald and Ted G. Jelen}

integration, they are independent domains with often conflicting influences on political behavior.

${ }^{10}$ The individual coefficients, the slope dummies, tell us only whether the coefficient for each group (Southern and non-Southern) is statistically distinguishable from zero. In a case where one coefficient is statistically significant and another is not, we cannot assume that the two slopes are significantly different from each other. The pooled variance t-test does enable us to identify such cases.

${ }^{11}$ While there is a general consensus among sociologists of religion on the effects of religious pluralism (or homogeneity), there is little agreement on the mechanisms by which religious socialization occurs in different markets. Although some analysts (Iannaccone 1991; Stark and Finke 2002) emphasize economic styles of incentives, others (Olson 2002; Bruce 2002) seek to account for differences in religious behavior by reference to sociological theories which focus on the dynamics of identity formation.

\section{REFERENCES}

Bauman, Mark. 2003. Southern Jewish Women and Their Social Service Organizations. Journal of American Ethnic History 22:34-78.

Bauman, Mark. 1996. The Southerner as American: Jewish Style. Cincinnati, OH: American Jewish Archives.

Berger, Peter. 1969. The Sacred Canopy: Elements of a Sociological Theory of Religion. Garden City, NY: Anchor.

Black, Earl, and Merle Black. 2002. The Rise of Southern Republicanism. Cambridge, MA: Harvard University Press.

Brown, Thad A. 1981. On Contextual Change and Partisan Attributes. British Journal of Political Science 11:427-447.

Bruce, Steve. 2002. The Poverty of Economism or the Social Limits on Maximizing. Pp. 167-186 in Sacred Markets, Sacred Canopies: Essays on Religious Markets and Religious Pluralism, ed. Ted G. Jelen. Lanham, MD: Rowman \& Littlefield.

Bullock, Charles S. III, and Mark J. Rozell. 2003. Introduction: Southern Politics in the Twenty-First Century. In The New Politics of the Old South, $2 \mathrm{~d}$ ed., eds. Charles S. Bullock, III and Mark J. Rozell. Lanham, MD: Rowman \& Littlefield.

Clark John A., and Charles Y. Prysby, eds. 2005. Southern Political Party Activists: Patterns of Conflict and Change, 1991-2001. Lexington: University Press of Kentucky (forthcoming).

Dinnerstein, Leonard. 1973. Southern Jewry and the Desegregation Crisis, 1954-1970. American Jewish Historical Quarterly 62:231-241.

Finke, Roger, and Rodney Stark. 1992. The Churching of America, 1776-1992. New Brunswick, NJ: Rutgers University Press.

Forman, Seth. 1997. The Unbearable Whiteness of Being Jewish: Desegregations in the South and the Crisis of Jewish Liberalism. American Jewish History 85:121-142.

Green, John C., Lyman A. Kellstedt, Corwin E. Smidt, and James L. Guth. 2003. The Soul of the South: Religion and Southern Politics at the Millennium. Pp. 283-298 in The New Politics of the Old South, $2 \mathrm{~d}$ ed., eds. Charles S. Bullock, III and Mark J. Rozell. Lanham, MD: Rowman \& Littlefield.

Greenberg, Cheryl. 1998. The Southern Jewish Community and the Struggle for Civil Rights. Pp. 123-164 in African Americans and Jews in the Twentieth Century: 
Studies in Convergence and Conflict, eds. V.P. Franklin, Nancy L. Grant, Harold M. Kletnick, and Genna Rae McNeil. Columbia: University of Missouri Press.

Hanushek, Eric Alan, and John E. Jackson. 1977. Statistical Methods for Social Scientists. New York: Academic Press.

Hood, M.V. III, Quentin Kidd, and Irwin R. Morris. 2004. The Reintroduction of Elephas Maximus to the Southern United States: The Rise of Republican State Parties, 1960-2000. American Politics Research 32:68-101.

Hyman, Paula E. 1992. Was There a "Jewish Politics" in Western and Central Europe. Pp. 105-118 in The Quest for Utopia: Jewish Political Ideas and Institutions through the Ages, ed. Zvi Gitelman. Armonk, NY: M.E. Sharpe.

Iannaccone, Laurence R. 1991. The Consequence of Religious Market Structure. Rationality and Society 3:156-177.

Jelen, Ted G. 2004. Reflections on Scholarship in Religion and Southern Politics. Paper presented at the Citadel Symposium on Southern Politics, Charleston, SC, March.

Jelen, Ted G. 2002. Reflections in the "New Paradigm": Unfinished Business and an Agenda for Research. Pp. 187-203 in Sacred Markets, Sacred Canopies: Essays on Religious Markets and Religious Pluralism, ed. Ted G. Jelen. Lanham, MD: Rowman \& Littlefield.

Kotler-Berkowitz, Laurence A. 2002. Social Cleavages and Political Divisions: A Comparative Analysis of British, American and South African Jews in the 1990s. Journal of Modern Jewish Studies 1:204-233.

Lamis, Alexander P. 1984. The Two-Party South. New York: Oxford University Press.

Lazerwitz, Bernard, J. Allen Winter, and Arnold Dashefsky. 1988. Localism, Religiosity, Orthodoxy and Liberalism: The Case of Jews in the United States. Social Forces 67:229-242.

Legge, Jerome S. 1995. Explaining Jewish Liberalism in the US: An Exploration of Socioeconomic, Religious and Communal Living Variables. Social Science Quarterly 76:124-141.

Medding, Peter Y. 1977. Towards a General Theory of Jewish Political Interests and Behaviour. Jewish Journal of Sociology 19:115-144.

Mendelsohn, Ezra. 1993. On Modern Jewish Politics. New York, NY: Oxford University Press.

Mohl, Raymond A. 1999. South of the South?: Jews, Blacks, and the Civil Rights Movement in Miami, 1945-1960. Journal of American Ethnic History 18:1-19.

Olson, Daniel V.A. 2002. Competing Notions of Religious Competition and Conflict in Theories of Religious Economies. Pp. 133-166 in Sacred Markets, Sacred Canopies: Essays on Religious Markets and Religious Pluralism, ed. Ted G. Jelen. Lanham, MD: Rowman \& Littlefield.

Putnam, Robert D. 1966. Political Attitudes and the Local Community. American Political Science Review 60:640-654.

Reed, John Shelton. 1979. Ethnicity in the South: Some Observations on the Acculturation of Southern Jews. Ethnicity 6:97-106.

Rieder, Jonathan. 1985. Canarsie: The Jews and Italians of Brooklyn Against Liberalism. Cambridge, MA: Harvard University Press.

Singer, David, and Grossman, Lawrence, eds. 2003. American Jewish Year Book 2003. New York: American Jewish Committee.

Svonkin, Stuart. 1997. Jews Against Prejudice: American Jews and the Fight for Civil Liberties. New York: Columbia University Press.

Wald, Kenneth D., and Michael D. Martinez. Jewish Religiosity and Political Attitudes in the United States and Israel. Political Behavior 23:377-397. 
116 | Kenneth D. Wald and Ted G. Jelen

Webb, Clive. 2001. Fight Against Fear: Southern Jews and Black Civil Rights. Athens: University of Georgia Press.

Webb, Clive. 1998. Closing Ranks: Montgomery Jews and Civil Rights, 1954-1960. Journal of American Studies 32:463-481.

Whitfield, S.J. 1988. The Braided Identity of Southern Jewry. American Jewish History 77:363-387. 